\title{
A COMPARATIVE STUDY ON OCTAPAC CULTURE OF HDFC \& AXIS BANK
}

\section{SASMITA NAYAK}

Assistant Professor, College of Engineering and Technology, Bhubaneswar, Odisha, India

\begin{abstract}
This research paper aim to study of what the value of OCTAPAC culture is, and compares the OCTAPAC culture of two private sector bank operated in Bhubaneswar. OCTAPAC culture refers to the degree of openness, confrontation, trust, autonomy, pro-activity, authenticity and collaboration that exist in the organization. The study of OCTAPAC culture of any organization helps us in giving proper training to the employees for maintaining a healthy environment and it also helps in dealing with various problems that exist in the organization. The main objective of the study is to study the organizational culture of two private sector bank operated in Bhubaneswar and to identify and measure the perceived organizational culture and its various dimensions.
\end{abstract}

KEYWORDS: Human Resource, HRD Climate, Confrontation, Trust \& Authenticity

Received: Dec 10, 2018; Accepted: Dec 30, 2018; Published: Jan 24, 2019; Paper Id.: IJHRMRFEB201914

\section{INTRODUCTION}

Culture plays very vital role in an organization because it gives an organization a strong competitive advantage. The ways organization operates, its values, visions, norms, beliefs, assumptions, systems, symbols is called the organization culture. The organization should focus on these aspects of culture and these are positive in out look to produce the greatest positive result in terms of organization outcomes. This collective behaviors \& beliefs that are taught to new members of the organization as a way of perceiving and feeling. It also influences the way people \& groups interact with each other and external interested parties \& the organization. Employee efficiency must continually be enhance, sharpened and utilized. It is only possible by enabling the organization culture. A strong culture enables an organization to achieve excellent performance.

\section{DIMENSIONS OCTAPAC}

The dimensions of OCTAPAC culture are openness, confrontation, Trust, Authenticity, pro-action, autonomy and collaboration which are essential for a strong and successful organization. A culture with OCTAPAC values has the greater chance of achieving high involvement and satisfaction, team work, growth and free flow of communication within the organization.

- Openness \& Risk Taking: Employees feel free to express their ideas \& the organization is willing to take risks \& experiment with new ideas \& new ways of doing things. The degree of openness of the organization is an important factor in determining the nature of various dimensions of HRD being designed.

- Confrontation: Employees face the problems \& work jointly with others concerned to find its solution. They face the issues squarely without hiding them or avoiding them for fear of hurting each other. 
- Trust: A minimum level of trust may be deemed necessary for the introduction of the performance appraisal system and other elements of HRD. Employees department \& groups trust each other \& can be relied upon to 'do' whatever they say they will.

- Authenticity: It is the value underlying trust. It is the willingness of a person to acknowledge the feelings he/she has, and accept him-self or her-self as well as others who relate to him/her as persons.

- Pro-activity: Employees are action - oriented, willing to take initiative \& show a high degree of pro-activity. They anticipate issues and act or respond to the needs of the future.

- Autonomy: It is the willingness to use power without fear, and helping others to do the same. Employees have some freedom to act independently within the boundaries imposed by their role or job.

- Collaboration: Collaboration involves working together and using one another's strength for a common cause. Individuals, instead of solving their problems by themselves, share their concerns with one another and prepare strategies, work out plans of action, and implement them together.

\section{REVIEW OF LITERATURE}

Oriol Iglesias, Alfons Sauquet, Jordi Montana (2011) concluded that the two key shared values required to successfully put relationship marketing into effect are client orientation and a high degree of concern for employees. Furthermore, another six shared values (trust, commitment, teamwork, innovation, flexibility, and results orientation) also seem to facilitate the development of a relationship marketing orientation, according to their study.

Martin (2002) studied that culture is deeply held assumptions,, meaning and beliefs of employees.

Scherin's (1992) suggested culture is "under the Water line" which invisible when researching more about culture, it is the recouritng of stories, rituals and interpretation of jargons.

Amabile (1996) suggested six components shows differenation between high creativity climate and low creativity climate, (a) organisational encouragement (b) Supervising encouragement (c) work group supports (d) Freedom (f) sufficient resource and challenges.

Krishna and Rao (1997) surveyed the organizational climate of the BHEL which shows that the environment of openness works well among the middle and senior managers in the company while the value of experimentation was responded to favorably among the middle and senior managers. A study conducted by Rohmetra (1998) on banking sector of J \& K space for determining the HRD climate showed that the environment is less open for employees and found that an intimate degree of trust is enjoyed in the bank.

Collin \& Amabile (1999) had suggested organisation culture and climate depends on individual creativity and innovation.

Anghe (1989) studied that motivation is important for creativity and innovation, also intrisinic motivation is more powerful than extrisinic motivation.

Feist (1999) identified in his research that creative person are more self confidence, autonomy, into version and independence. 
Deal and Kennedy (1982) and peters and waterman (1982) suggested that organisational culture can influence performance and employee commitment in an organisation.

Top management and leaders of organisation must understand the importance of organisation culture because it directly relates to organisation response with changing demands of business environment (Agrawal and Tyagi, 2010)

M. Srimannarayana (2009) conducted a study in Human Resource Development in manufacturing sector and found that OCTAPAC culture has been more prevalent than HRD Mechanisms and General HRD climate and a moderate HRD climate has been prevalent in the organisations surveyed. He suggested that organisation may introduce fair employee welfare programmes and reward systems to improve employee satisfaction levels and subsequently to gain advantage from satisfied workers to increase productivity.

\section{OBJECTIVE}

- $\quad$ To study organization culture of Axis Bank and HDFC Bank.

- $\quad$ To study the difference in culture in Axis Bank and HDFC Bank.

\section{RESEARCH METHODS}

The present study is based on both primary and secondary data. The primary data has been collected from 100 executives of two private sector banks, who have regional office are in Bhubaneswar. For the purpose of the study the climate survey questionnaire consisting of 38 items on HRD climate was used. The questionnaire was developed b T V Rao and E. Abharam at XLRI centre for HRD and that assess an organization's General Climate, HRD Mechanism and OCTAPAC Culture. The views were collected against five point scale (5-All most always true, 4- Mostly true, 3Sometimes true, 2- Rarely true and 1- Not at all true)

\section{DATA ANALYSIS}

Data analysis was carried out by using statistical package for social science (SPSS). The One-way ANOVA test was applied to the test the significant differences in OCTAPAC Culture in private banks taken under the study.

Table 1: Authenticity

\begin{tabular}{|c|l|c|c|c|c|c|c|}
\hline Sl. & \multicolumn{1}{|c|}{ Factors } & \multicolumn{3}{|c|}{ HDFC } & \multicolumn{3}{c|}{ AXIS } \\
\cline { 3 - 8 } No. & & Mean & SD & SE & Mean & SD & SE \\
\hline 1 & $\begin{array}{l}\text { Career opportunities are } \\
\text { pointed out to juniors by senior } \\
\text { officers in the organization }\end{array}$ & 3.16 & 0.681 & 0.096 & 3.46 & 0.613 & 0.087 \\
\hline \multirow{2}{*}{2} & $\begin{array}{l}\text { The organization's future plans } \\
\text { are made known to the } \\
\text { managerial staff to help them } \\
\text { develop their juniors and } \\
\text { prepare them for future. }\end{array}$ & 2.82 & 1.224 & 0.173 & 3.6 & 0.606 & 0.086 \\
\hline & \multicolumn{1}{|c|}{ Group Average } & $\mathbf{2 . 9 9}$ & $\mathbf{0 . 9 5}$ & $\mathbf{0 . 1 3}$ & $\mathbf{3 . 5 3}$ & $\mathbf{0 . 6 1}$ & $\mathbf{0 . 0 9}$ \\
\hline
\end{tabular}

Authenticity: Authenticity is the congruence between what one feels, says and does. Authenticity is openess and bridges the communication gap. The group average of the item was found 3.53 with SD of 0.61 in Axis Bank and average 2.99 with SD of 0.95 in HDFC Bank. It shows from the average level of authenticity culture exist in banks. 
Table 2: Pro-activity

\begin{tabular}{|c|l|c|c|c|c|c|c|}
\hline \multicolumn{1}{|c|}{ SI. } & \multicolumn{1}{|c|}{ Factors } & \multicolumn{3}{c|}{ HDFC } & \multicolumn{3}{c|}{ AXIS } \\
\cline { 3 - 8 } No. & Mean & SD & SE & Mean & SD & SE \\
\hline 1 & $\begin{array}{l}\text { The psychological climate in this } \\
\text { organization is very conducive to any } \\
\text { employee interested in developing himself } \\
\text { by acquiring new knowledge and skills. }\end{array}$ & 2.74 & 1.121 & 0.159 & 3.08 & 0.944 & 0.134 \\
\hline \multirow{2}{*}{2} & $\begin{array}{l}\text { Employees are encouraged to take } \\
\text { initiative and do things on their own } \\
\text { without having to wait for instructions } \\
\text { from supervisors }\end{array}$ & 3.04 & 0.88 & 0.124 & 3.36 & 0.749 & 0.106 \\
\hline & \multicolumn{1}{|c|}{ Group Average } & $\mathbf{2 . 8 9}$ & $\mathbf{1 . 0 0}$ & $\mathbf{0 . 1 4}$ & $\mathbf{3 . 2 2}$ & $\mathbf{0 . 8 5}$ & $\mathbf{0 . 1 2}$ \\
\hline
\end{tabular}

Proaction: Proactivity means taking initiative and preventive actions. In proactive culture employees are encourage to take initiative and risk. The group average of the items found 3.22 with SD of 0.85 in Axis bank and mean 2.89 with Sd of 1.00 in HDFC Bank. This shows employees initiative and taking risk at an average level. Proactively culture of Axis Bank is better than HDFC Bank.

Table 3: Autonomy

\begin{tabular}{|c|l|c|c|c|c|c|c|}
\hline S. & \multicolumn{1}{|c|}{ Factors } & \multicolumn{3}{|c|}{ HDFC } & \multicolumn{3}{c|}{ AXIS } \\
\cline { 3 - 8 } No. & \multicolumn{1}{|c|}{ Mean } & SD & SE & Mean & SD & SE \\
\hline 1 & $\begin{array}{l}\text { Employees are encouraged to take } \\
\text { initiative and do things on their } \\
\text { own without having to wait for } \\
\text { instructions from supervisors. }\end{array}$ & 3.04 & 0.88 & 0.124 & 3.36 & 0.749 & 0.106 \\
\hline & $\begin{array}{l}\text { The psychological climate in this } \\
\text { organization is very conducive to } \\
\text { any employee interested in } \\
\text { developing himself by acquiring } \\
\text { new knowledge and skills. }\end{array}$ & 2.74 & 1.121 & 0.159 & 3.08 & 0.944 & 0.134 \\
\hline 3 & $\begin{array}{l}\text { Delegation of authority to } \\
\text { encourage juniors to develop } \\
\text { handling higher responsibilities is } \\
\text { quite common in this organization }\end{array}$ & 3.08 & 0.804 & 0.114 & 3.58 & 0.883 & 0.125 \\
\hline 4 & $\begin{array}{l}\text { When seniors delegate authority to } \\
\text { juniors, the juniors use it as an } \\
\text { opportunity for development. }\end{array}$ & 3.22 & 1.016 & 0.144 & 3.76 & 0.625 & 0.088 \\
\hline & $\quad$ Group Average & $\mathbf{3 . 0 4}$ & $\mathbf{0 . 8 8}$ & $\mathbf{0 . 1 2 4}$ & $\mathbf{3 . 3 6}$ & $\mathbf{0 . 7 4 9}$ & $\mathbf{0 . 1 0 6}$ \\
\hline
\end{tabular}

Autonomy: Autonomy is using and giving freedom to take decision and act in one's own decision. It means respecting and encouraging individual and role autonomy. Respondents were asked to rate four items relating to level of autonomy. The group mean found to be 3.36 with SD of 0.749 in Axis Bank and mean 3.04 with SD of 0.88 in HDFC bank. It shows average autonomy culture exist in both banks. In Axis bank autonomy culture is better than HDFC bank. It further shows employee's initiation is at an average level.

Table 4: Collaboration

\begin{tabular}{|c|l|c|c|c|c|c|c|}
\hline Sl. & \multicolumn{1}{|c|}{ Factors } & \multicolumn{3}{|c|}{ HDFC } & \multicolumn{3}{c|}{ AXIS } \\
\cline { 3 - 8 } No. & \multicolumn{1}{|c|}{ Mean } & SD & SE & Mean & SD & SE \\
\hline 1 & $\begin{array}{l}\text { People in this organization are } \\
\text { helpful to each other }\end{array}$ & 3.04 & 0.856 & 0.121 & 3.18 & 0.896 & 0.127 \\
\hline 2 & $\begin{array}{l}\text { Team spirit is of high order in this } \\
\text { organization }\end{array}$ & 3.48 & 1.054 & 0.149 & 3.5 & 0.735 & 0.104 \\
\hline
\end{tabular}




\begin{tabular}{|c|l|c|c|c|c|c|c|}
\hline \multicolumn{2}{|c|}{ Table 4: Contd., } & & & & & \\
\hline 3 & $\begin{array}{l}\text { The organization's future plans are } \\
\text { made known to the managerial } \\
\text { staff to help them develop their } \\
\text { juniors and prepare them for future }\end{array}$ & 2.82 & 1.224 & 0.173 & 3.6 & 0.606 & 0.086 \\
\hline & Group Average & $\mathbf{3 . 1 1}$ & $\mathbf{1 . 0 4}$ & $\mathbf{0 . 1 5}$ & $\mathbf{3 . 4 3}$ & $\mathbf{0 . 7 5}$ & $\mathbf{0 . 1 1}$ \\
\hline
\end{tabular}

Collaboration: Collaboration means supporting others and work in team spirit. The average mean is 3.43 with SD 0.75 and 3.11 with SD 1.04 in Axis bank and HDFC bank respectively. The finding shows that team work culture exist in banks at average level.

Table 5: Openness

\begin{tabular}{|c|c|c|c|c|c|c|c|}
\hline \multirow{2}{*}{$\begin{array}{l}\text { Sl. } \\
\text { No. }\end{array}$} & \multirow{2}{*}{ Factors } & \multicolumn{3}{|c|}{ HDFC } & \multicolumn{3}{|c|}{$\overline{\text { AXIS }}$} \\
\hline & & Mean & SD & SE & Mean & SD & SE \\
\hline 1 & $\begin{array}{l}\text { Employees in this } \\
\text { organizations are very } \\
\text { informal and do not hesitate to } \\
\text { discuss their personal } \\
\text { problems with their supervisor }\end{array}$ & 2.74 & 1.209 & 0.171 & 2.54 & 1.328 & 0.188 \\
\hline 2 & $\begin{array}{l}\text { People in this organization } \\
\text { have any fixed mental } \\
\text { impressions about each other }\end{array}$ & 3.08 & 1.047 & 0.148 & 3.1 & 0.909 & 0.129 \\
\hline 3 & $\begin{array}{l}\text { Employees do not feel afraid } \\
\text { about their expression of/or } \\
\text { Culture discussion of their } \\
\text { feelings with their superiors. }\end{array}$ & 3.02 & 1.097 & 0.155 & 3.34 & 0.593 & 0.084 \\
\hline 4 & $\begin{array}{l}\text { Employees are not afraid to } \\
\text { express or discuss their } \\
\text { Feelings with their } \\
\text { subordinates. }\end{array}$ & 2.9 & 1.282 & 0.181 & 3.42 & 0.859 & 0.122 \\
\hline & Group Average & 2.935 & 1.159 & 0.164 & 3.100 & 0.922 & 0.131 \\
\hline
\end{tabular}

Openness: Openness is the expression of feeling and thought with others without any hesitation. Openness is both receiving and giving. It is also includes receiving feedback positively and sharing information openly. The respondents are requested to rate the four items that shows openness. As shown in Table 5 the group means score of HDFC 2.935 with a standard deviation 1.159 and mean score of Axis 3.100 with a standard deviation 0.922 . The finding of this section shows openness culture of Axis bank better than HDFC bank.

Table 6: Confrontation

\begin{tabular}{|c|c|c|c|c|c|c|c|}
\hline \multirow{2}{*}{$\begin{array}{l}\text { Sl. } \\
\text { No. }\end{array}$} & \multirow{2}{*}{ Factors } & \multicolumn{3}{|c|}{ HDFC } & \multicolumn{3}{|c|}{ AXIS } \\
\hline & & Mean & SD & SE & Mean & SD & SE \\
\hline 1 & $\begin{array}{l}\text { Employees in this organizations are } \\
\text { very informal and do not hesitate to } \\
\text { discuss their personal problems with } \\
\text { their supervisor }\end{array}$ & 2.74 & 1.209 & 0.171 & 2.54 & 1.328 & 0.188 \\
\hline 2 & $\begin{array}{l}\text { Employees are not afraid to express } \\
\text { or discuss their feelings with their } \\
\text { subordinate }\end{array}$ & 2.9 & 1.282 & 0.181 & 3.42 & 0.859 & 0.122 \\
\hline 3 & $\begin{array}{l}\text { When problem arise people discuss } \\
\text { these problems openly and try to } \\
\text { solve them rather than keep accusing } \\
\text { each other behind the back }\end{array}$ & 2.68 & 1.096 & 0.155 & 3.48 & 0.707 & 0.1 \\
\hline & Group Average & 2.740 & 1.209 & 0.171 & 2.540 & 1.328 & 0.188 \\
\hline
\end{tabular}


Confrontation: Confrontation is solving the problem without hiding the problem. By confrontation more problems are solved and more roles are clarified in the organization. Then respondents were asked to rate four items as shown in Table 6. The mean average score is 2.740 with SD 1.289 in HDFC bank where in Axis bank mean is 2.540 and 1.328. The finding of this section shows confrontation is very low in both banks.

Table 7: Trust

\begin{tabular}{|c|l|c|c|c|c|c|c|}
\hline Sl. & \multicolumn{1}{|c|}{ Factors } & \multicolumn{3}{|c|}{ HDFC } & \multicolumn{3}{c|}{ AXIS } \\
\cline { 3 - 8 } No. & Mean & SD & SE & Mean & SD & SE \\
\hline 1 & $\begin{array}{l}\text { People trust each other in } \\
\text { this organization }\end{array}$ & 3.44 & 1.072 & 0.152 & 3.54 & 0.503 & 0.071 \\
\hline 2 & $\begin{array}{l}\text { People in this } \\
\text { organization are helpful to } \\
\text { each other. }\end{array}$ & 3.04 & 0.856 & 0.121 & 3.18 & 0.896 & 0.127 \\
\hline 3 & $\begin{array}{l}\text { Team spirit is of high } \\
\text { order in this organization. }\end{array}$ & 3.48 & 1.054 & 0.149 & 3.5 & 0.735 & 0.104 \\
\hline & $\quad$ Group Average & $\mathbf{3 . 3 2 0}$ & $\mathbf{0 . 9 9 4}$ & $\mathbf{0 . 1 4 1}$ & $\mathbf{3 . 4 0 7}$ & $\mathbf{0 . 7 1 1}$ & $\mathbf{0 . 1 0 1}$ \\
\hline
\end{tabular}

Trust: Trust is reflected in accepting what another person says at face value. Trust is one of important ingredients in organisation. The outcome of trust includes reduced stress, less conflict, better cooperation and healthy climate. Respondents were asked to rate three items that are related to trust culture. The group average mean score 3.407 with SD 0.711 in Axis bank and in HDFC bank mean score 3.320 with SD of 0.994 . This shows average culture of trust exists in organization.

\section{CONCLUSIONS}

Though there is a fundamental difference between two banks, this research proves that there are some factors which are same in both the banks. 3+ mean values indicating that most of the factors are influencing effectively on both the banks except confrontation. Both the banks should work on to develop problem solving techniques to their employees without hiding the problems, as the mean values shows below 3 which indicates poor in confrontation factor. In HDFC bank Proaction and Autonomy factors found to be less than of Axis bank, shows that HDFC bank should provide maximum possible proactivity and autonomy to the employees so that they take initiative, decision and actions at their source at the gross root level and should be encouraged to step outside established roles to accept challenges beyond the scope and structure of the existing job description as now it is the era of multitasking.

\section{REFERENCES}

1. Krishna P.M., Rao P.S. (1997): Organisational at HRD climate in BHEL: An empirical study. The Journal of Public Administration, 43: 209-216.

2. Amabile, T.M., Conti, R., Coon, H., Lazenby, J., \& Herron, M. (1996). Assessing the work environment for creativity. Academy of Management Journal. 39 (5) 1154-1185

3. Angle, H. L. (1989). Psychology and organisational innovation. In A. H. Van de Ven, H. L. Angle. \& M. Poole (Eds). Research on the management of innovations: The Minnesota studies (pp. 135-170). New York: Harper \& Row.

4. Oriol Iglesias, Alfons Sauquet, Jordi Montaña(2011): The role of corporate culture in relationship marketing, strategy, European journal of marketing, vol.45

5. Agrawal, R.K. and Tyagi, A. (2010) 'Organisational culture in Indian organisations: an empircal study', Int. J. Indian Culture and Business Management, Vol. 3, No. 1, pp.68-87. 
6. Collins, M. A \& Amabile. T. M. (1999). Motivation and creativity. In R. J. Stermberg (Ed.), Handbook of creativity (pp. $297-$ 312). Cambridge. UK: Cambridge University Press.

7. Deal, T. E. And Kennedy, A.A. (1982). Corporate Cultures. Menlo Park: Addison Wesley Publishing Co

8. E.H. Schein: Organisational culture and leadership Jossey-Boss, San Francisco, 1985 P.9

a. Feist. G.. (1999). The influence of personality on artistic and scientific creativity. In R. J. Sternberg $\quad($ Ed), $\quad$ Handbook $\quad$ of creativity (pp.273-296). Cambridge. UK: Cambridge University Press.

9. Martin, J. (2002). Organisational culture: Mapping the terrain. Thousand Oaks. CA: sage. Mufeed, S. A., \& Hamdani, Q. A. (2013). HRD mechanisms in health care sector in Jammu \& Kashmir : a comparative study. European scientific journal, $9(21)$.

10. Schein, E. H. (1992), Organisational culture and leadership (2nd ed.). San Francisco Jossey-Bass.

11. Srimamarayana, M. (2009) "Human Resources development in Manufacturing Sector", Management and change vol (13) Nov (2), 131-141.

12. W.B. Turnstall: cultural transition at AT\&T, Sloan Management review, 25, 1983 pp 1-12 ] 
